\title{
PENERAPAN AHP DAN TOPSIS UNTUK PENILAIAN KELAYAKAN KREDIT PADA BPR CENTRADANA KAPUAS PONTIANAK
}

\author{
Irawan Wingdes ${ }^{1}$ \\ Tri Widayanti ${ }^{2}$ \\ Juruan Sistem Informasi , STMIK Pontianak ${ }^{1,2}$ \\ e-mail:irawan.wingdes@gmail.com, triwidayanti69@gmail.com
}

Diterima: 5 Juni 2017/ Disetujui : 12 Juni 2017

\begin{abstract}
Financing for business or consumption is one of the main purpose of a bank. BPR is mini part of Indonesian banking system that functions like conventional banks with limited or smaller role. BPR also finances for car loans. In practice, when administrative assessments for car loan applications are not met, subjective assessment is needed to further assess car loan applications. The purpose of this study is to develop decision support for the latter problem. This study employs AHP and TOPSIS as decision support method. 5C's are used for assesment which results in highest preference in Character (0.36), followed by Capacity (0.28), Capital (0.19), Collateral (0.14), Condition (0.04). Fifteen sub criterias are also developed to further assess the loan and TOPSIS is used for alternative selection. The result of this study proves AHP and TOPSIS are reliable for supporting multi criteria decision making, especially in assessing and approving car credit loan at BPR Centradana Kapuas Pontianak.
\end{abstract}

Keywords : CDM, AHP, TOPSIS, Car Loan Application

\begin{abstract}
ABSTRAK
Penyaluran kredit merupakan salah satu fungsi dari bank. BPR merupakan bagian dari bank yang mempunyai fungsi mirip dengan bank sehingga penyaluran kredit merupakan salah satu kegiatan utama BPR. Penyaluran kredit mobil khususnya memerlukan pertimbangan tambahan selain persyaratan administratif. Pertimbangan tambahan sering merupakan unsur subjektif sehingga memerlukan pendukung pembuat keputusan. Tujuan dari penelitian ini adalah mengembangkan pendukung keputusan untuk penyaluran kredit mobil di BPR Centradana Kapuas. Penelitian menggunakan metode AHP sebagai pembobot dan TOPSIS sebagai pemilih alternatif pada aplikasi kredit. Penelitian berhasil mengembangkan 5 kriteria utama dengan preferensi AHP yaitu Character 0.36, Capacity 0.28, Capital 0.19, Collateral 0.14, Condition 0.04. Lima belas sub kriteria tambahan juga berhasil dikembangkan untuk digunakan pada analisis TOPSIS. Hasil penelitian menunjukkan bahwa bahwa pendukung keputusan berhasil membantu pembuatan keputusan yang memerlukan banyak pertimbangan atau Multi Criteria Decision Making. Dengan menggunakan AHP dan TOPSIS, unsur subjektifitas dapat dibobot dan dikalkulasi sehingga keputusan lebih objektif dan terukur pada penyaluran kredit mobil di BPR Centradana Kapuas Pontianak.
\end{abstract}

Kata kunci : MCDM, AHP, TOPSIS, Kredit Mobil 


\section{PENDAHULUAN}

Bank merupakan badan usaha yang menghimpun dana dari masyarakat dalam bentuk simpanan dan menyalurkannya kepada masyarakat dalam bentuk kredit dan atau bentuk-bentuk lainnya dalam rangka meningkatkan taraf hidup masyarakat [1].Perbankan Indonesia dalam menjalankan fungsinya berasaskan prinsip kehati-hatian. Fungsi utama perbankan Indonesia adalah sebagai penghimpun dan penyalur dana masyarakat serta bertujuan untuk menunjang pelaksanaan pembangunan nasional dalam rangka meningkatkan pemerataan pembangunan dan hasil-hasilnya, pertumbuhan ekonomi dan stabilitas nasional, ke arah peningkatan taraf hidup rakyat banyak. Pada tahun 2011, jumlah bank di Indonesia sebanyak 120 dengan 4 bank pemerintah dan 116 bank swasta, sedangkan untuk BPR sebanyak 1837 dengan BPR konvensional sebanyak 1683, dan BPR Syariah sebanyak 154 [2].

Bank Perkreditan Rakyat (BPR) adalah Bank yang melaksanakan kegiatan usaha secara konvensional atau berdasarkan prinsip syariah, yang dalam kegiatannya tidak memberikan jasa dalam lalu lintas pembayaran. Kegiatan BPR jauh lebih sempit jika dibandingkan dengan kegiatan bank umum karena BPR dilarang menerima simpanan giro, kegiatan valas, dan perasuransian.

Usaha yang dapat dilaksanakan oleh BPR adalah sebagai berikut: Menghimpun dana dari masyarakat dalam bentuk simpanan berupa deposito berjangka, tabungan, dan atau bentuk lainnya yang dipersamakan dengan itu. Memberikan kredit, menyediakan pembiayaan dan penempatan dana berdasarkan prinsip syariah,sesuai dengan ketentuan yang ditetapkan oleh Bank Indonesia.Menempatkan dananya dalam bentuk Sertifikat Bank Indonesia (SBI), deposito berjangka, sertifikat deposito, dan atau tabungan pada bank lain. [3]

Secara keseluruhan, kredit BPR di Pontianak mencapai Rp 597,86 miliar. Dari jumlah tersebut, sebesar 50,83 persen disalurkan kepada kredit usaha dalam bentuk modal kerja sebesar Rp 212 miliar, Rp 92 miliar untuk investasi dan kredit konsumsi sebesar Rp 294 miliar. [4]. BPR Centradana Kapuas termasuk ke dalam salah satu BPR dengan jumlah aset 50-100 miliar di daerah Pontianak. BPR ini menerima predikat sangat bagus dari infobank selama 3 tahun yaitu pada tahun 2011, 2013, dan 2014. Produk kredit yang diberikan oleh perusahaan ini meliputi kredit modal kerja, kredit pemilikan rumah (KPR), kredit konsumtif, kredit pegawai, dan kredit sepeda motor dan mobil, kredit pendidikan, kredit resepsi pernikahan serta produk pembiayaan lainnya. [5].

Proses evaluasi kredit pada bank adalah aktivitas yang dilakukan untuk menentukan kemampuan pengembalian dari kredit yang diberikan dan kalkulasi resiko kredit. Tujuan utamanya adalah meminimalkan resiko kredit dengan menentukan kemampuan membayar dari nasabah yang akan mengajukan kredit. Proses evaluasi kredit bersifat subjektif dan biasanya dilakukan oleh eksekutif yang telah mempunyai pengalaman [6].

Pada BPR Centradana Kapuas, pengucuran kredit masih mengandalkan hasil survei lapangan dan keputusan akhir masih mengandalkan pengalaman dan intuisi dari pemilik langsung. Oleh karena itu, untuk mempertahankan dan memperbaiki kualitas kredit, perlu dikembangkan penunjang keputusan pada bagian pengucuran kredit.

Penunjang keputusan pada bagian kredit menjadi permasalahan dari penelitian ini dimana metode AHP dan TOPSIS digunakan peneliti untuk mengembangkan penunjang keputusan tersebut. Penelitian sebelumnya menunjukkan bahwa AHP dapat digunakan untuk membantu pengambilan keputusan kredit komersial [6]. AHP juga telah digunakan untuk mengevaluasi kredit pada pabrik di negara Turki [7]. AHP dan TOPSIS juga telah digunakan juga secara bersama-sama pada aplikasi limit kredit pada bank [8]. Pada penelitian-penelitian sebelumnya telah menunjukkan bahwa AHP dan TOPSIS tepat digunakan sebagai alat penunjang keputusan pada bidang pengucuran kredit pada perusahaan.

Penunjang keputusan yang dikembangkan ini khususnya ditujukan untuk bagian pengucuran kredit mobil yang merupakan salah satu bagian yang penting bagi BPR Centradana Kapuas. Dengan penunjang keputusan, pengambilan keputusan akan lebih objektif dan dapat menjadi salah satu media transfer pengetahuan dari pemilik perusahaan maupun petugas lapangan kepada suksesi baik itu manajer baru maupun karyawan lapangan baru. 


\section{METODE PENELITIAN}

Penelitian ini dilakukan dengan mengadaptasi penelitian sebelumnya [9] dimana 2 metode dignakan untuk pendukung keputsan yaitu Analytical Hierarchy Process (AHP) dan Technique for Order by Similarity to Ideal Solution (TOPSIS). AHP digunakan untuk menentukan bobot kepentingan dari setiap kriteria dan sub kriteria pemberian kredit, kemudian TOPSIS digunakan untuk memilih alternatif pemohon kredit yang memerlukan pertimbangan.

AHP dan TOPSIS merupakan bagian dari Multiple Criteria Decision Analysis (MCDA) atau Multiple Criteria Decision Making (MCDM). MCDA terutama berguna untuk mendukung keputusan subjektif yang melibatkan beberapa alternatif keputusan dengan beberapa alternatif kriteria kinerja oleh seseorang ataupun beberapa orang pembuat keputusan [9].

\subsection{Metode AHP}

AHP merupakan metode pengambilan keputusan yang melibatkan sejumlah kriteria dan alternatif yang dipilih berdasarkan pertimbangan semua kriteria terkait [10].Kriteria memiliki derajat kepentingan yang berbeda-beda, demikian pula halnya alternatif memiliki preferensi yang berbeda menurut masing-masing kriteria yang ada.Penilaian kriteria dan alternatif dilakukan dengan membuat perbandingan berpasangan (pairwise comparison) dengan menggunakan skala 1 sampai 9. Nilai dan definisi pendapat kualitatif dari skala 1 sampai 9 Saaty dapat diukurdan mempunyai arti yang dapat dilihat di tabel 1[11].

Nilai-nilai perbandingan relatif dari seluruh alternatif kriteria disesuaikan dengan penilaian pembuat keputusanuntuk menghasilkan bobot dan prioritas. Bobot dan prioritas dihitung dengan matriks atau diselesaikan melalui penyelesaian matematis. Apabila dijabarkan dalam tahapan, maka AHP dilakukan dengan beberapa tahapan berikut ini:

1. Membuat struktur hierarki.

2. Membangun pairwise comparison matrix.

Dengan asumsi $n$ atribut, perbandingan berpasangan atribut i dengan atribut $\mathrm{j}$ menghasilkan matriks $A_{n \times n}$ dimana $a_{i j}$ menunjukkan pentingnya perbandingan atribut $i$ dengan atribut $j$. Dalam matriks, $a_{i j}$ $=1$ ketika $\mathrm{i}=\mathrm{j}$ dan $\mathrm{a}_{\mathrm{ji}}=1 / \mathrm{a}_{\mathrm{ij}}$.

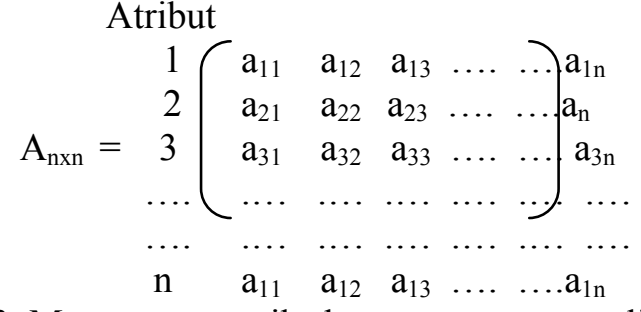

3. Menyusun matriks keputusan ternormalisasi :

$$
\begin{aligned}
& \mathrm{C}_{\mathrm{ij}}=\mathrm{a}_{\mathrm{ij}} \mathrm{E}_{\mathrm{m}=1}^{\mathrm{n}} \text { at } \\
& I=1,2,3, \ldots \ldots ., n, j=1,2,3, \ldots \ldots ., n
\end{aligned}
$$

4.Menyusun Matriks Keputusan Normalisasi Terbobot.

$$
\begin{aligned}
& \mathrm{w}_{\mathrm{i}}=\sum_{j=1}^{\mathrm{n}} \mathrm{atj} / \mathrm{n}, \mathrm{I}=1,2,3, \ldots \ldots \mathrm{n} \\
& \mathrm{w}=\left(\begin{array}{c}
\mathrm{w}_{1} \\
\mathrm{w}_{2} \\
\cdot \\
\cdot \\
\mathrm{w}_{\mathrm{n}}
\end{array}\right)
\end{aligned}
$$

5. Menghitung Eigenvector dan matriks baris

$\mathrm{E}=\mathrm{N}^{\text {th }}$ rootvalue $/ \sum \mathrm{N}^{\text {th }}$ rootvalue

Rowmatrix $=\sum_{i=2}^{n} \operatorname{aikj} * e_{j 1}$

6.Menghitung Eigenvalue maksimal, $\lambda_{\max }$. 


$$
\lambda_{\max }=\text { Rowmatrix / E }
$$

7.Menghitung Consistency Index and Consistency Ratio

$$
\begin{aligned}
& \mathrm{CI}=\left(\lambda_{\max }-\mathrm{n}\right) /(\mathrm{n}-1) \\
& \mathrm{CR}=\mathrm{CI} / \mathrm{RI}
\end{aligned}
$$

Hasil perhitungan akan menghasilkan Logical Consistency. Pemilihan kriteria harus konsisten. Konsistensi disini memiliki dua makna. Pertama,objek-objek yang serupa bisa dikelompokkan sesuai dengan keseragaman dan relevansi. Kedua, menyangkut tingkat hubungan antar objek yang didasarkan pada kriteria tertentu. Konsistensi dapat dihitung dengan menggunakan rumus Consistency Index $(\mathrm{CI})=(\lambda$ maks $) / n$. Dimana $n=$ banyaknya elemen. Setelah itu perlu menghitung Consistency Ratio(CR) dengan rumus: $\mathrm{CR}=\mathrm{CI} / \mathrm{RI}$. Jika $\mathrm{CR}$ kurang dari $10 \%$ maka penilaian pembuat keputusan dianggap konsisten dan bila lebih dari $10 \%$ berarti tidak konsisten dan harus diulang penilaiannya. RI adalah Random Consistency dengan ukuran matriks 1 sampai 9 dengan nilai sesuai ukuran matriks yang dapat dilihat pada tabel 2 .

Tabel 1 : Skala Penilaian Perbandingan Pasangan Saaty

\begin{tabular}{|c|l|}
\hline IntensitasKepentingan & \multicolumn{1}{c|}{ Keterangan } \\
\hline 1 & Kedua elemen sama penting \\
\hline 3 & $\begin{array}{l}\text { Elemen yang satu sedikit lebih penting dari pada elemen } \\
\text { lainnya }\end{array}$ \\
\hline 5 & Elemen yang satu lebih penting dari pada elemen lainnya \\
\hline 7 & $\begin{array}{l}\text { Satu elemen jelas lebih mutlak penting dari pada elemen } \\
\text { lainnya }\end{array}$ \\
\hline 9 & Satu elemen mutlak penting dari pada elemen lainnya \\
\hline 2468 & Nilai - nilai antara dua nilai pertimbangan yang berdekatan \\
\hline
\end{tabular}

Tabel 2. Nilai Rata-Rata Konsistensi

\begin{tabular}{|c|c|}
\hline Ukuran Matriks & Random Consistency \\
\hline 1 dan 2 & 0,00 \\
\hline 3 & 0,58 \\
\hline 4 & 0,90 \\
\hline 5 & 1,12 \\
\hline 6 & 1,24 \\
\hline 7 & 1,32 \\
\hline 8 & 1,41 \\
\hline 9 & 1,45 \\
\hline 10 & 1,49 \\
\hline
\end{tabular}

\subsection{Metode TOPSIS}

TOPSIS merupakan suatu metode pendukung keputusan yang menggunakan prinsip bahwa alternatif yang terpilih harus mempunyai jarak terdekat dari solusi ideal positif dan terjauh dari solusi ideal negatif dari sudut pandang geometris dengan menggunakan jarak Euclidean untuk menentukan kedekatan relatif dari suatu alternatif dengan solusi optimal.

Solusi ideal positif didefinisikan sebagai jumlah dari seluruh nilai terbaik yang dapat dicapai untuk setiap atribut, sedangkan solusi negatif ideal terdiri dari seluruh nilai terburuk yang dicapai untuk setiap atribut[12]. TOPSIS mempertimbangkan keduanya, jarak terhadap solusi ideal positif dan jarak terhadap solusi ideal negatif dengan mengambil kedekatan relatif terhadap solusi ideal positif. Berdasarkan perbandingan terhadap jarak relatifnya, susunan prioritas alternatif bisa dicapai.

Metode TOPSIS ini merupakan salah satu metode yang digunakan sebagai upaya untuk menyelesaikan permasalahan MCDA. Secara umum, metode TOPSIS memiliki langkah-langkah sebagai berikut : [13] 
a. Menggambarkan alternatif $(m)$ dan kriteria $(n)$ kedalam sebuah matriks, dimana $X_{i j}$ adalah pengukuran pilihan dari alternatif ke-I dan kriteria ke-j.

$$
\mathrm{D}=\left[\begin{array}{lll}
x_{11} & x_{12}= & x_{1} \\
x_{21} & x_{22}= & x_{2} \\
x_{i 1} & x_{22}= & x_{4}
\end{array}\right.
$$

b. Membangun normalized decision matrix Elemen $\mathrm{r}_{\mathrm{ij}}$ hasil dari normalisasi decision matrix $\mathrm{R}$ dengan metode Euclidean length of a vector adalah :

$$
\mathrm{r}_{\mathrm{ij}}=\frac{x}{\sqrt{\sum_{\xi}^{\text {mg }}}}
$$

Dimana $: \mathrm{r}_{\mathrm{ij}}=$ hasil dari normalisasi matriks keputusan $\mathrm{R}$

$\mathrm{i}=1,2,3, \ldots, \mathrm{m}$;

$\mathrm{j}=1,2,3, \ldots, \mathrm{n}$;

c. Membangun weighted normalized decision matrix. Setelah dinormalisasi, setiap kolom pada matriks $\mathrm{R}$ dikalikan dengan bobot $\left(\mathrm{W}_{\mathrm{j}}\right)$, maka normalisasi bobot matriks $\mathrm{V}$ adalah:

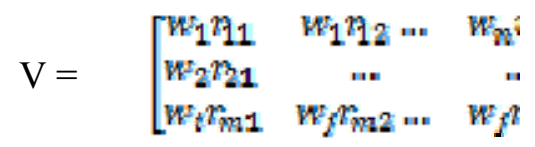

d. Menentukan solusi ideal positif dan solusi ideal negatif.

$$
\begin{aligned}
\mathrm{A}^{+} & =\left\{\left(\max \mathrm{V}_{\mathrm{ij}} \mid \mathrm{j} € \mathrm{~J}\right),\left(\min \mathrm{V}_{\mathrm{ij}} \mid \mathrm{j} € \mathrm{~J}^{\prime}\right), \mathrm{i}=1,2,3, \ldots, \mathrm{m}\right\} \\
& =\left\{\mathrm{V}_{1}^{+}, \mathrm{V}_{2}^{+}, \ldots, \mathrm{V}_{\mathrm{n}}^{+}\right\} \\
\mathrm{A}^{-} & =\left\{\left(\min \mathrm{V}_{\mathrm{ij}} \mid \mathrm{j} € \mathrm{~J}\right),\left(\max \mathrm{V}_{\mathrm{ij}} \mid \mathrm{j} € \mathrm{~J}^{\prime}\right), \mathrm{i}=1,2,3, \ldots, \mathrm{m}\right\} \\
& =\left\{\mathrm{V}_{1}^{-}, \mathrm{V}_{2}^{-}, \ldots, \mathrm{V}_{\mathrm{n}}^{-}\right\} \\
\mathrm{J} & =\{\mathrm{j}=1,2,3, \ldots . \mathrm{n} \text { dan } \mathrm{j} \text { merupakan benefit criteria }\} \\
\mathrm{J}^{\prime} & =\{\mathrm{j}=1,2,3, \ldots . \mathrm{n} \text { dan } \mathrm{j} \text { merupakan cost criteria })\}
\end{aligned}
$$

e. Menghitung separation measure. Separation measure merupakan pengukuran jarak dari suatu alternatif ke solusi ideal positif dan solusi ideal negatif.

$$
\begin{aligned}
& \mathrm{S}_{\mathrm{i}}^{+=} \sqrt{\sum_{t=1}^{n} \mathrm{~V}_{t j}-2} \\
& \mathrm{~S}_{\mathrm{i}}^{-}=\sqrt{\sum_{i=1}^{n} \mathrm{~V}_{t j}-{ }^{-2}}
\end{aligned}
$$

$$
\text { Dengan } \mathrm{i}=1,2,3 \ldots \ldots \ldots \mathrm{m}
$$

f. Menghitung nilai preferensi untuk setiap alternatif untuk menentukan ranking tiap-tiap alternatif yang ada.

$$
\mathrm{C}_{\mathrm{i}}^{+}=\frac{+}{s_{i}^{+}}
$$

Dimana $0<\mathrm{C}_{\mathrm{i}}^{+}<1$ dan $\mathrm{I}=1,2,3, \ldots \ldots, \mathrm{m}$

\subsection{Kriteria Kredit Mobil}

Berdasarkan hasil wawancara dengan pihak BPR Centradana Kapuas Pontianak didapatkan 5 kriteria penting yang berpengaruh dalam penentuan pemberian kredit mobil. Secara prinsip, bank menggunakan kriteria 5C, yaitu Character, Capacity, Capital, Collateral, dan Condition.

Walaupun 5c sudah cukup lengkap sebagai acuan untuk memberikan pertimbangan 
pengucuran kredit. Namun, sering dalam praktek pertimbangan lain maupun pertimbangan dengan mempertimbangkan faktor lain sangat diperlukan misalnya seorang nasabah mungkin saja faktor Characternya cocok untuk dikucurkan kredit, tetapi faktor Capitalnya belum mencukupi. Karena itu, dikembangkan kriteria lanjutan sesuai kondisi lapangan yang terjadi pada pihak BPR yang diteliti.

Kriteria dan subkriteria yang dikembangkan lebih lanjut dari hasil wawancara dapat dilihat pada tabel 3 berikut ini:

Tabel 3. Kriteria dan Sub Kriteria Pemberian Kredit Mobil

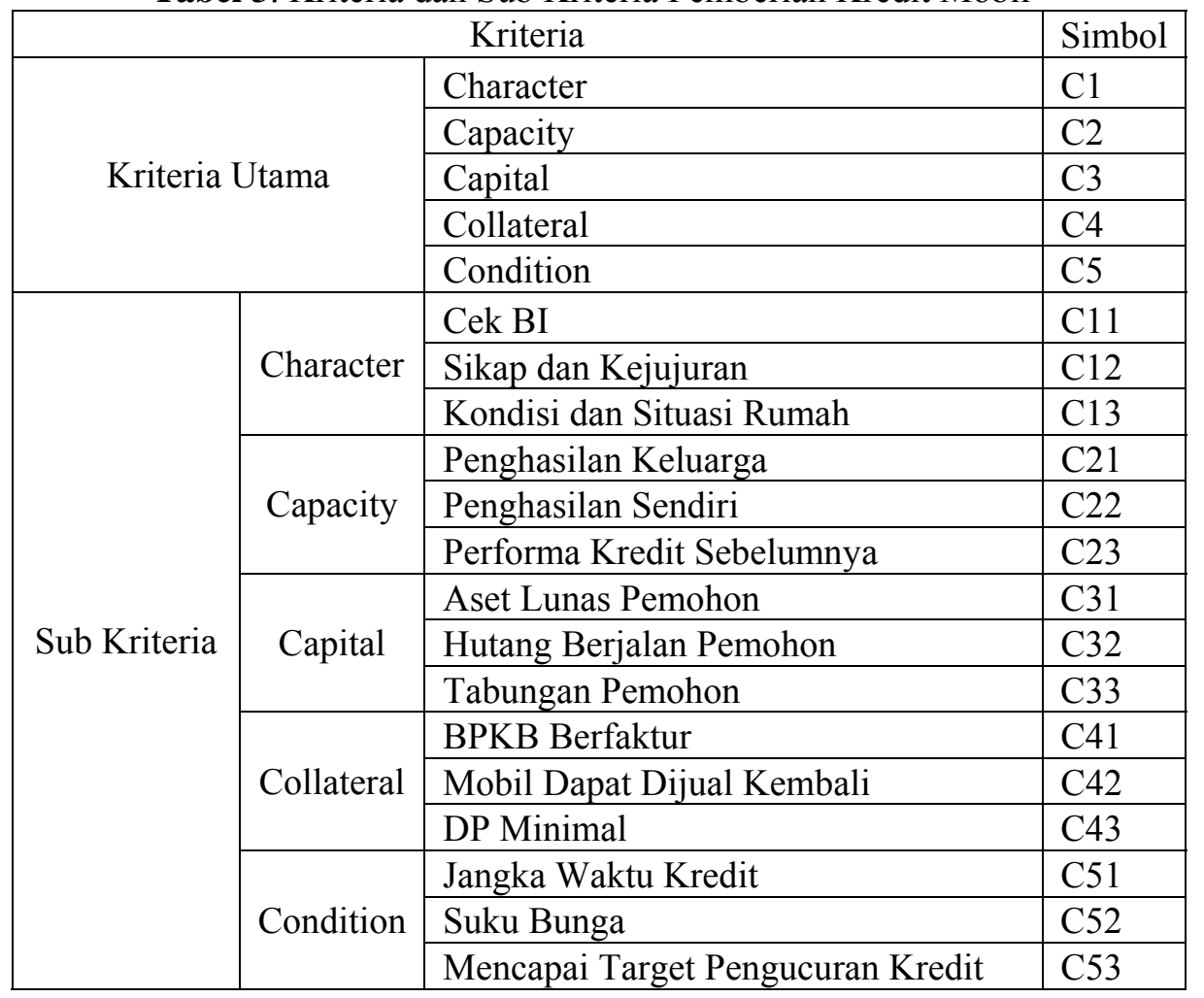

Character berkaitan dengan karakter dari pemohon kredit. Sebelum dikucurkan kredit, terutama untuk kredit mobil, pihak bank harus melakukan cek BI untuk melihat kualitas dari pemohon kredit, apakah sebelumnya sering menunggak, apakah sudah di black list dari BI. Cek BI adalah faktor yang sangat penting, tetapi ada saatnya menjadi terlalu kaku seperti hanya menunggak beberapa hari saja sudah memicu sistem BI untuk memblack-list pemohon kredit. Pada kasus-kasus tertentu seperti itu maka perlu pendukung keputusan untuk memberikan hasil yang lebih objektif dengan mempertimbangkan kriteria lainnya seperti sikap dan kejujuran pemohon serta kondisi dan situasi rumah pada saat dilakukan survei oleh petugas lapangan.

Capacity berkaitan dengan kemampuan konsumen mengembalikan kredit kepada bank. Sering terjadi pihak pemohon kredit sebenarnya tidak mampu untuk mencicil bulanan, atau penghasilannya hanya mampu untuk mencicil pinjaman saja dan tidak cukup untuk kebutuhan primer lainnya. Tetapi di dalam rumah atau keluarga pemohon terdapat keluarga atau pihak lain yang mempunyai penghasilan tambahan dan bila digabungkan, mampu membantu memenuhi kebutuhan primer dan mengangsur cicilan. Pada kondisi seperti ini, apabila tidak dikucurkan kredit, perusahaan kehilangan pendapatan potensial, tetapi apabila dikucurkan, secara prinsipal pemohon kredit tidak memenuhi persyaratan. Keputusan seperti ini memerlukan pertimbangan tambahan disertai juga dengan performa kredit sebelumnya yang bisa didapatkan dengan survei petugas lapangan.

Capital berkaitan dengan aset dikurangi hutang yang dimiliki oleh pemohon, yang dinilai disini adalah aset total yang telah dikumpulkan oleh pemohon yang sudah lunas, hutang pemohon yang masih berjalan dan jumlah tabungan yang dimiliki oleh pemohon pada saat mengajukan kredit. Sub kriteria tersebut dapat dikumpulkan oleh petugas lapangan pada saat survei dilakukan.

Collateral berkaitan dengan jaminan yang diberikan oleh pemohon kredit. Khusus untuk kredit mobil, BPKB bila memiliki faktur akan lebih disukai karena faktor legalitas, tetapi faktur 
bersifat opsional sehingga memerlukan pertimbangan dengan pertimbangan kriteria lain seperti kelayakan mobil yang dijaminkan pada kredit (apakah bila kredit bermasalah nantinya mobilnya masih dapat dijual kembali setelah ditarik oleh pihak bank) dan apakah DP minimal tercapai. Sering terjadi DP minimal 30\% tidak tercapai tetapi tidak terlalu jauh dari target. Misalnya hanya $20-25 \%$, sehingga apabila langsung ditolak akan mengurangi potensi penghasilan perusahaan.

Condition mempunyai sub kriteria jangka waktu kredit, suku bunga, dan mencapai target pengucuran kredit. Jangka waktu kredit yang pendek akan lebih disukai oleh perusahaan, suku bunga yang diberikan juga tidak kaku (dapat diatur tinggi rendah oleh petugas sesuai kondisi lapangan), dan apakah pada saat mengucurkan kredit, target pengucuran sudah tercapai oleh perusahaan. Ketiga pertimbangan ini perlu dilakukan untuk mendukung keputusan subjektif pemberian kredit bagi konsumen yang tidak memenuhi syarat administratif.

\section{HASIL DAN PEMBAHASAN}

\subsection{Bobot Kepentingan Kriteria Utama}

Perbandingan berpasangandilakukan untuk proses AHP, nilai perbandingan dari lima kriteria yaitu Character, Capacity, Capital, Collateral dan Condition didapat dari kuesioner yang diberikan kepada manajer BPR Centradana Kapuas bagian kredit mobildan hasil perbandingan, normalisasi dan konsistensi dapat dilihat pada tabel 4.

Tabel 4.Matrik Perbandingan, Normalisasi, Konsistensi Kriteria Utama

\begin{tabular}{|l|r|r|r|r|r|r|r|r|r|r|r|}
\hline & Character & \multicolumn{2}{|c|}{ Capacity } & \multicolumn{2}{c|}{ Capital } & \multicolumn{2}{c|}{ Collateral } & Condition & EV \\
\hline Character & 1 & 0.40 & 2 & 0.50 & 2 & 0.30 & 3 & 0.37 & 6 & 0.21 & 0.36 \\
\hline Capacity & 0.50 & 0.20 & 1 & 0.25 & 3 & 0.45 & 2 & 0.25 & 7 & 0.25 & 0.28 \\
\hline Capital & 0.50 & 0.20 & 0.33 & 0.08 & 1 & 0.15 & 2 & 0.25 & 7 & 0.25 & 0.19 \\
\hline Collateral & 0.33 & 0.13 & 0.50 & 0.13 & 0.5 & 0.08 & 1 & 0.12 & 7 & 0.25 & 0.14 \\
\hline Condition & 0.17 & 0.07 & 0.14 & 0.04 & 0.14 & 0.02 & 0.14 & 0.02 & 1 & 0.04 & 0.04 \\
\hline JUMLAH & 2.50 & 0.93 & 3.98 & 0.96 & 6.64 & 0.98 & 8.14 & 0.98 & 28 & 1 & 1 \\
\hline \multicolumn{4}{|c|}{ Consistency Index (CI) } & \multicolumn{1}{c|}{ CI $=0.080406$ RI $=1.12$} \\
\hline
\end{tabular}

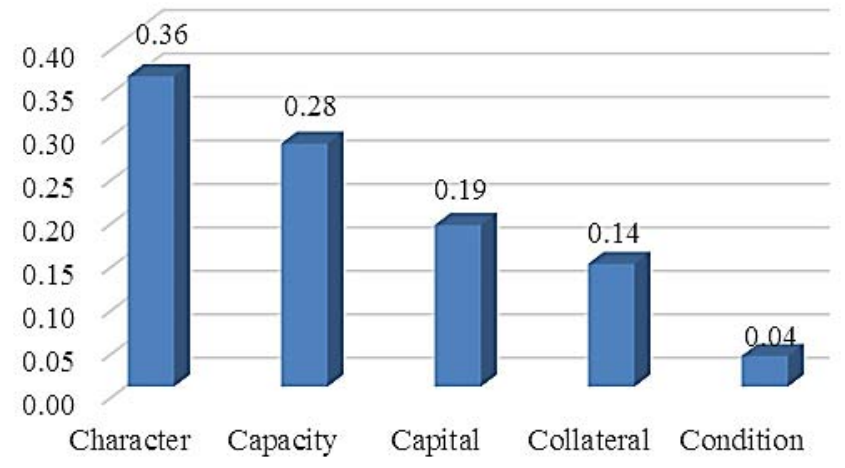

Gambar 1. Preferensi Kriteria Utama

Pada tabel 4, dapat dilihat perbandingan berpasangan yang oleh manajer pemberi kredit di BPR dimana didapatkan hasil akhir berupa Eigen Value atau bobot setiap elemen yang didapat dari merata-ratakan setiap baris kriteria sesuai rumus. Eigen Value dari setiap kriteria utama adalah Character 0.36, Capacity 0.28, Capital 0.19, Collateral 0.14, dan Condition 0.04. Dari hasil EV dapat disimpulkan bahwa kriteria paling penting dalam pemberian kredit mobil adalah kriteria Character, diikuti dengan Capacity dan Capital. Sedangkan yang paling tidak penting adalah Condition.

Untuk menilai konsistensi kriteria, perhitungan CR dilakukan sesuai rumus CR dengan RI menggunakan matriks $5 \times 5$ yang bernilai 1.12 . Hasil CR menunjukkan nilai 0.071791 yang berarti lebih rendah dari 0.1 sehingga dianggap konsisten. [10,11] 


\subsection{Bobot Kepentingan Sub Kriteria}

Selanjutnya perbandingan berpasangan dilakukan pada sub kriteria dan dapat dilihat hasilnya pada tabel 5. Dari Eigen Value dapat disimpulkan bahwa untuk sub kriteria Character yang paling penting adalah kriteria Sikap dan Kejujuran, Kondisi dan Situasi Rumah, diikuti dengan Cek BI. Sedangkan pada Capacity yang paling diutamakan adalah Penghasilan Sendiri, diikuti dengan Penghasilan Keluarga dan Performa Kredit Sebelumnya.

Pada Capital, yang paling diutamakan adalah Hutang Berjalan Pemohon, Aset Lunas Pemohon dan terakhir adalah Tabungan Pemohon. Untuk Collateral, yang paling diutamakan adalah DP Minimal, Mobil Dapat Dijual Kembali, dan BPKB Berfaktur. Pada sub kriteria terakhir yaitu Condition, yang paling tidak diutamakan adalah Jangka Waktu Kredit, diikuti dengan Mencapai Target Pengucuran Kredit dan yang paling penting adalah Suku Bunga.

Semua perbandingan berpasangan diuji konsistensi dengan RI bernilai 0.58 (bermatriks $3 \times 3$ ) dan semuanya memenuhi syarat dengan nilai dibawah 0.1 atau $10 \%$, dengan demikian dapat disimpulkan bahwa perbandingan untuk sub kriteria telah memenuhi syarat.

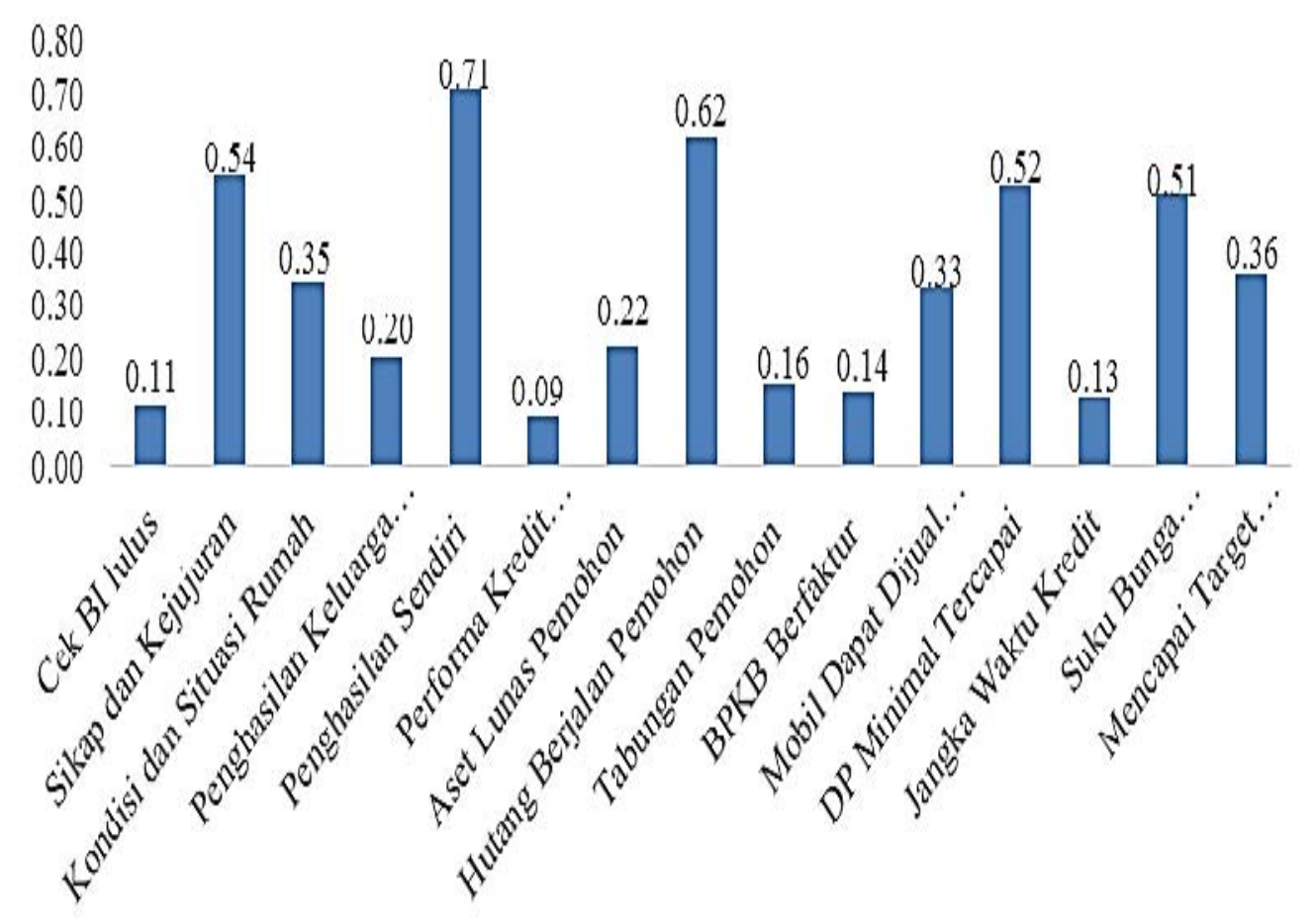

CHARACTER

\begin{tabular}{|l|r|r|r|r|r|r|r|}
\hline & \multicolumn{2}{|c|}{ C11 } & \multicolumn{2}{c|}{$\mathrm{C} 12$} & \multicolumn{2}{c|}{$\mathrm{C} 13$} & $\mathrm{EV}$ \\
\hline $\mathrm{C} 1$ & & 0.1 & 0.2 & 0.1 & 0.2 & 0.0 & 0.1 \\
1 & 1 & 1 & 5 & 4 & 5 & 8 & 1 \\
\hline $\mathrm{C} 1$ & & 0.4 & & 0.5 & & 0.6 & 0.5 \\
2 & 4 & 4 & 1 & 7 & 2 & 2 & 4 \\
\hline $\mathrm{C} 1$ & & 0.4 & & 0.2 & & 0.3 & 0.3 \\
3 & 4 & 4 & 0.5 & 9 & 1 & 1 & 5 \\
\hline $\mathrm{JM}$ & & & 1.7 & & 3.2 & & \\
$\mathrm{~L}$ & 9 & 1 & 5 & 1 & 5 & 1 & 1 \\
\hline \multicolumn{3}{|l|}{ Consistency Index } & \multicolumn{2}{c|}{$\mathrm{CI}=0.03 \mathrm{RI}=0.58$} \\
\hline \multicolumn{3}{|l|}{ Consistency Ratio } & $\mathrm{CR}=0.05 /$ Konsisten \\
\hline
\end{tabular}

CAPACITY

\begin{tabular}{|l|r|r|r|r|r|r|r|}
\hline & $\mathrm{C} 21$ & \multicolumn{2}{|c|}{ C22 } & \multicolumn{2}{c|}{ C23 } & EV \\
\hline & 1.0 & 0.1 & 0.2 & & & 0.3 & 0.2 \\
$\mathrm{C} 21$ & 0 & 6 & 0 & 0.15 & 3 & 0 & 0 \\
\hline & 5.0 & 0.7 & 1.0 & & & 0.6 & 0.7 \\
$\mathrm{C} 22$ & 0 & 9 & 0 & 0.73 & 6 & 0 & 1 \\
\hline & 0.3 & 0.0 & 0.1 & & & 0.1 & 0.0 \\
$\mathrm{C} 23$ & 3 & 5 & 7 & 0.12 & 1 & 0 & 9 \\
\hline & 6.3 & & 1.3 & & 1 & & \\
JML & 3 & 1 & 7 & 1 & 0 & 1 & 1 \\
\hline Consistency Index & \multicolumn{1}{c}{$\mathrm{CI}=0.05 \mathrm{RI}=0.58$} \\
\hline
\end{tabular}


CAPITAL

\begin{tabular}{|c|c|c|c|c|c|c|c|}
\hline & \multicolumn{2}{|c|}{$\mathrm{C} 31$} & \multicolumn{2}{|c|}{$\mathrm{C} 32$} & \multicolumn{2}{|c|}{$\mathrm{C} 33$} & EV \\
\hline C31 & 1 & $\begin{array}{r}0.1 \\
8\end{array}$ & $\begin{array}{r}0.2 \\
5\end{array}$ & $\begin{array}{r}0.1 \\
6\end{array}$ & $\begin{array}{r}2.0 \\
0\end{array}$ & $\begin{array}{r}0.3 \\
3\end{array}$ & 0.22 \\
\hline C32 & 4 & $\begin{array}{r}0.7 \\
3\end{array}$ & $\begin{array}{r}1.0 \\
0\end{array}$ & $\begin{array}{r}0.6 \\
3\end{array}$ & $\begin{array}{r}3.0 \\
0\end{array}$ & $\begin{array}{r}0.5 \\
0\end{array}$ & 0.62 \\
\hline C33 & $\begin{array}{r}0 . \\
5\end{array}$ & $\begin{array}{r}0.0 \\
9\end{array}$ & $\begin{array}{r}0.3 \\
3\end{array}$ & $\begin{array}{r}0.2 \\
1\end{array}$ & $\begin{array}{r}1.0 \\
0\end{array}$ & $\begin{array}{r}0.1 \\
7\end{array}$ & 016 \\
\hline & $\begin{array}{r}5 . \\
5\end{array}$ & 1.0 & 1.5 & 1.0 & 6.0 & 1.0 & \\
\hline JML & 0 & 0 & 8 & $\underline{0}$ & 0 & 0 & 1.00 \\
\hline \multicolumn{4}{|c|}{ Consistency Index } & \multicolumn{4}{|c|}{$\mathrm{CI}=0.05 \mathrm{RI}=0.58$} \\
\hline \multicolumn{4}{|c|}{ Consistency Ratio } & \multicolumn{4}{|c|}{$\mathrm{CR}=0.09 /$ Konsisten } \\
\hline
\end{tabular}

COLLATERAL

\begin{tabular}{|c|c|c|c|c|c|c|c|}
\hline 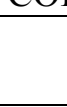 & \multicolumn{2}{|c|}{ C41 } & \multicolumn{2}{|c|}{ C42 } & \multicolumn{2}{|c|}{ C43 } & $\begin{array}{l}\mathrm{E} \\
\mathrm{V}\end{array}$ \\
\hline $\mathrm{C} 4$ & & 0.1 & 0.3 & . & & 0.1 & 1 \\
\hline 1 & 1 & 4 & 3 & 1 & 0.33 & 8 & 4 \\
\hline $\mathrm{C} 4$ & & 0.4 & & 0 & & 0.2 & 3 \\
\hline 2 & 3 & 3 & 1 & 3 & 0.5 & 7 & 3 \\
\hline $\begin{array}{l}\mathrm{C} 4 \\
3\end{array}$ & 3 & $\begin{array}{r}0.4 \\
3\end{array}$ & 2 & $\begin{array}{l}0 \\
\dot{6}\end{array}$ & 1 & $\begin{array}{r}0.5 \\
5\end{array}$ & $\begin{array}{l}5 \\
2\end{array}$ \\
\hline $\begin{array}{l}\mathrm{JM} \\
\mathrm{L}\end{array}$ & 7 & 1 & $\begin{array}{r}3.3 \\
3\end{array}$ & 1 & 1.83 & 1 & 1 \\
\hline \multicolumn{4}{|c|}{ Consistency Index } & \multicolumn{4}{|c|}{$\mathrm{CI}=0.03 \mathrm{RI}=0.58$} \\
\hline & 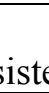 & $\mathrm{y}$ & & & $\begin{array}{l}\mathrm{CR}= \\
\text { Kons }\end{array}$ & $\begin{array}{l}.05 / \\
\text { ten }\end{array}$ & \\
\hline
\end{tabular}

CONDITION

\begin{tabular}{|c|c|c|c|c|c|c|c|}
\hline & \multicolumn{2}{|c|}{ C51 } & \multicolumn{2}{|c|}{$\mathrm{C} 52$} & \multicolumn{2}{|c|}{$\mathrm{C} 53$} & EV \\
\hline $\mathrm{C} 51$ & 1 & 0.13 & 0.33 & 0.18 & 0.25 & 0.08 & 0.13 \\
\hline $\mathrm{C} 52$ & 3 & 0.38 & 1 & 0.55 & 2 & 0.62 & 0.51 \\
\hline $\mathrm{C} 53$ & 4 & 0.5 & 0.5 & 0.27 & 1 & 0.31 & 0.36 \\
\hline JUMLAH & 8 & 1 & 1.83 & 1 & 3.25 & 1 & \\
\hline \multicolumn{4}{|c|}{ Consistency Index (CI) } & \multicolumn{4}{|c|}{$\mathrm{CI}=0.05 \mathrm{RI}=0.58$} \\
\hline \multicolumn{4}{|c|}{ Consistency Ratio (CR) } & \multicolumn{4}{|c|}{$\mathrm{CR}=0.09 /$ Konsisten } \\
\hline
\end{tabular}

Tabel 6. Skor Pemohon Kredit Berdasarkan Sub Kriteria

\begin{tabular}{|c|c|c|c|c|c|c|c|c|c|c|c|c|c|c|c|}
\hline $\begin{array}{l}\text { Alternat } \\
\text { if }\end{array}$ & $\begin{array}{l}\mathrm{C} 1 \\
1 \\
\end{array}$ & $\begin{array}{l}\text { C1 } \\
2 \\
\end{array}$ & $\begin{array}{l}\text { C1 } \\
3\end{array}$ & $\begin{array}{l}\mathrm{C} 2 \\
1 \\
\end{array}$ & $\begin{array}{l}\mathrm{C} 2 \\
2 \\
\end{array}$ & $\begin{array}{l}\mathrm{C} 2 \\
3 \\
\end{array}$ & $\begin{array}{l}\mathrm{C} 3 \\
1 \\
\end{array}$ & $\begin{array}{l}\mathrm{C} 3 \\
2 \\
\end{array}$ & $\begin{array}{l}\mathrm{C} 3 \\
3 \\
\end{array}$ & $\begin{array}{l}\mathrm{C} 4 \\
1 \\
\end{array}$ & $\begin{array}{l}\text { C4 } \\
2 \\
\end{array}$ & $\begin{array}{l}\mathrm{C} 4 \\
3 \\
\end{array}$ & $\begin{array}{l}\text { C5 } \\
1 \\
\end{array}$ & $\begin{array}{l}\text { C5 } \\
2 \\
\end{array}$ & $\begin{array}{l}\text { C5 } \\
3 \\
\end{array}$ \\
\hline Susanto & 9 & 5 & 6 & 7 & 6 & 2 & 6 & 7 & 5 & 1 & 5 & 1 & 8 & 8 & 9 \\
\hline Dewi & 1 & 8 & 6 & 1 & 9 & 5 & 9 & 8 & 9 & 9 & 6 & 1 & 7 & 7 & 9 \\
\hline Agung & 1 & 7 & 6 & 8 & 3 & 8 & 7 & 9 & 8 & 9 & 7 & 1 & 8 & 7 & 9 \\
\hline Setiaji & 9 & 7 & 9 & 7 & 2 & 8 & 6 & 5 & 7 & 9 & 7 & 1 & 9 & 6 & 9 \\
\hline $\begin{array}{l}\text { Nurjana } \\
\mathrm{h}\end{array}$ & 9 & 8 & 7 & 9 & 5 & 2 & 9 & 8 & 6 & 9 & 7 & 1 & 6 & 7 & 1 \\
\hline Wisnu & 1 & 7 & 8 & 2 & 7 & 5 & 6 & 8 & 6 & 1 & 8 & 1 & 7 & 8 & 1 \\
\hline Purba & 1 & 8 & 7 & 9 & 8 & 5 & 8 & 7 & 6 & 1 & 9 & 9 & 8 & 7 & 1 \\
\hline Endang & 1 & 7 & 8 & 3 & 2 & 9 & 5 & 5 & 5 & 9 & 7 & 9 & 9 & 8 & 9 \\
\hline Maulid & 9 & 9 & 9 & 8 & 7 & 2 & 6 & 6 & 5 & 1 & 7 & 9 & 8 & 9 & 9 \\
\hline Herman & 9 & 6 & 5 & 9 & 9 & 9 & 8 & 7 & 6 & 9 & 5 & 9 & 5 & 7 & 1 \\
\hline & $\begin{array}{c}20 . \\
2\end{array}$ & $\begin{array}{c}23 . \\
0\end{array}$ & $\begin{array}{c}22 . \\
8\end{array}$ & $\begin{array}{c}22 . \\
0 \\
\end{array}$ & $\begin{array}{c}20 . \\
0\end{array}$ & $\begin{array}{c}19 . \\
4\end{array}$ & $\begin{array}{c}22 . \\
5\end{array}$ & $\begin{array}{c}22 . \\
5 \\
\end{array}$ & $\begin{array}{c}20 . \\
3 \\
\end{array}$ & $\begin{array}{c}22 . \\
1\end{array}$ & $\begin{array}{c}21 . \\
8\end{array}$ & $\begin{array}{c}18 . \\
2 \\
\end{array}$ & $\begin{array}{c}24 . \\
0\end{array}$ & $\begin{array}{c}23 . \\
5\end{array}$ & $\begin{array}{r}22 . \\
1\end{array}$ \\
\hline
\end{tabular}


Tabel 7. Normalized Decision Matrix

\begin{tabular}{|l|c|c|c|c|c|c|c|c|c|c|c|c|c|c|c|}
\hline Alternat & C1 & C1 & C1 & C2 & C2 & C2 & C3 & C3 & C3 & C4 & C4 & C4 & C5 & C5 & C5 \\
if & 1 & 2 & 3 & 1 & 2 & 3 & 1 & 2 & 3 & 1 & 2 & 3 & 1 & 2 & 3 \\
\hline & 0.4 & 0.2 & 0.2 & 0.3 & 0.3 & 0.1 & 0.2 & 0.3 & 0.2 & 0.0 & 0.2 & 0.0 & 0.3 & 0.3 & 0.4 \\
Susanto & 4 & 2 & 6 & 2 & 0 & 0 & 7 & 1 & 5 & 5 & 3 & 6 & 3 & 4 & 1 \\
\hline & 0.0 & 0.3 & 0.2 & 0.0 & 0.4 & 0.2 & 0.4 & 0.3 & 0.4 & 0.4 & 0.2 & 0.0 & 0.2 & 0.3 & 0.4 \\
Dewi & 5 & 5 & 6 & 5 & 5 & 6 & 0 & 6 & 4 & 1 & 8 & 6 & 9 & 0 & 1 \\
\hline & 0.0 & 0.3 & 0.2 & 0.3 & 0.1 & 0.4 & 0.3 & 0.4 & 0.3 & 0.4 & 0.3 & 0.0 & 0.3 & 0.3 & 0.4 \\
Agung & 5 & 0 & 6 & 6 & 5 & 1 & 1 & 0 & 9 & 1 & 2 & 6 & 3 & 0 & 1 \\
\hline & 0.4 & 0.3 & 0.3 & 0.3 & 0.1 & 0.4 & 0.2 & 0.2 & 0.3 & 0.4 & 0.3 & 0.0 & 0.3 & 0.2 & 0.4 \\
Setiaji & 4 & 0 & 9 & 2 & 0 & 1 & 7 & 2 & 4 & 1 & 2 & 6 & 7 & 5 & 1 \\
\hline Nurjana & 0.4 & 0.3 & 0.3 & 0.4 & 0.2 & 0.1 & 0.4 & 0.3 & 0.3 & 0.4 & 0.3 & 0.0 & 0.2 & 0.3 & 0.0 \\
h & 4 & 5 & 1 & 1 & 5 & 0 & 0 & 6 & 0 & 1 & 2 & 6 & 5 & 0 & 5 \\
\hline & 0.0 & 0.3 & 0.3 & 0.0 & 0.3 & 0.2 & 0.2 & 0.3 & 0.3 & 0.0 & 0.3 & 0.0 & 0.2 & 0.3 & 0.0 \\
Wisnu & 5 & 0 & 5 & 9 & 5 & 6 & 7 & 6 & 0 & 5 & 7 & 6 & 9 & 4 & 5 \\
\hline & 0.0 & 0.3 & 0.3 & 0.4 & 0.4 & 0.2 & 0.3 & 0.3 & 0.3 & 0.0 & 0.4 & 0.5 & 0.3 & 0.3 & 0.0 \\
Purba & 5 & 5 & 1 & 1 & 0 & 6 & 5 & 1 & 0 & 5 & 1 & 0 & 3 & 0 & 5 \\
\hline & 0.0 & 0.3 & 0.3 & 0.1 & 0.1 & 0.4 & 0.2 & 0.2 & 0.2 & 0.4 & 0.3 & 0.5 & 0.3 & 0.3 & 0.4 \\
Endang & 5 & 0 & 5 & 4 & 0 & 6 & 2 & 2 & 5 & 1 & 2 & 0 & 7 & 4 & 1 \\
\hline & 0.4 & 0.3 & 0.3 & 0.3 & 0.3 & 0.1 & 0.2 & 0.2 & 0.2 & 0.0 & 0.3 & 0.5 & 0.3 & 0.3 & 0.4 \\
Maulid & 4 & 9 & 9 & 6 & 5 & 0 & 7 & 7 & 5 & 5 & 2 & 0 & 3 & 8 & 1 \\
\hline & 0.4 & 0.2 & 0.2 & 0.4 & 0.4 & 0.4 & 0.3 & 0.3 & 0.3 & 0.4 & 0.2 & 0.5 & 0.2 & 0.3 & 0.0 \\
Herman & 4 & 6 & 2 & 1 & 5 & 6 & 5 & 1 & 0 & 1 & 3 & 0 & 1 & 0 & 5 \\
\hline
\end{tabular}

Tabel 8. Weighted Normalized Decision Matrix

\begin{tabular}{|c|c|c|c|c|c|c|c|c|c|c|c|c|c|c|c|}
\hline $\begin{array}{l}\text { Alternat } \\
\text { if }\end{array}$ & $\begin{array}{l}\mathrm{C} 1 \\
1\end{array}$ & $\begin{array}{l}\mathrm{C} 1 \\
2\end{array}$ & $\begin{array}{l}\mathrm{C} 1 \\
3\end{array}$ & $\begin{array}{l}\mathrm{C} 2 \\
1\end{array}$ & $\begin{array}{l}\mathrm{C} 2 \\
2\end{array}$ & $\begin{array}{l}\mathrm{C} 2 \\
3\end{array}$ & $\begin{array}{l}\mathrm{C} 3 \\
1\end{array}$ & $\begin{array}{l}\mathrm{C} 3 \\
2\end{array}$ & $\begin{array}{l}\mathrm{C} 3 \\
3\end{array}$ & $\begin{array}{l}\mathrm{C} 4 \\
1\end{array}$ & $\begin{array}{l}\mathrm{C} 4 \\
2\end{array}$ & $\begin{array}{l}\mathrm{C} 4 \\
3\end{array}$ & $\begin{array}{l}\mathrm{C} 5 \\
1\end{array}$ & $\begin{array}{l}\text { C5 } \\
2\end{array}$ & $\begin{array}{l}\mathrm{C} 5 \\
3\end{array}$ \\
\hline Susanto & $\begin{array}{c}0.0 \\
5\end{array}$ & $\begin{array}{c}0.1 \\
2\end{array}$ & $\begin{array}{c}0.0 \\
9\end{array}$ & $\begin{array}{c}0.0 \\
6\end{array}$ & $\begin{array}{c}0.2 \\
1\end{array}$ & $\begin{array}{c}0.0 \\
1\end{array}$ & $\begin{array}{c}0.0 \\
6\end{array}$ & $\begin{array}{c}0.1 \\
9\end{array}$ & $\begin{array}{c}0.0 \\
4\end{array}$ & $\begin{array}{c}0.0 \\
1\end{array}$ & $\begin{array}{c}0.0 \\
8\end{array}$ & $\begin{array}{c}0.0 \\
2\end{array}$ & $\begin{array}{c}0.0 \\
4\end{array}$ & $\begin{array}{c}0.1 \\
7\end{array}$ & $\begin{array}{c}0.1 \\
5\end{array}$ \\
\hline Dewi & $\begin{array}{c}0.0 \\
1\end{array}$ & $\begin{array}{c}0.1 \\
9\end{array}$ & $\begin{array}{c}0.0 \\
9\end{array}$ & $\begin{array}{c}0.0 \\
1\end{array}$ & $\begin{array}{c}0.3 \\
2\end{array}$ & $\begin{array}{c}0.0 \\
2\end{array}$ & $\begin{array}{c}0.0 \\
9\end{array}$ & $\begin{array}{c}0.2 \\
2\end{array}$ & $\begin{array}{c}0.0 \\
7\end{array}$ & $\begin{array}{c}0.0 \\
6\end{array}$ & $\begin{array}{c}0.0 \\
9\end{array}$ & $\begin{array}{c}0.0 \\
2\end{array}$ & $\begin{array}{c}0.0 \\
4\end{array}$ & $\begin{array}{c}0.1 \\
5\end{array}$ & $\begin{array}{c}0.1 \\
5\end{array}$ \\
\hline Agung & $\begin{array}{c}0.0 \\
1\end{array}$ & $\begin{array}{c}0.1 \\
6\end{array}$ & $\begin{array}{c}0.0 \\
9\end{array}$ & $\begin{array}{c}0.0 \\
7\end{array}$ & $\begin{array}{c}0.1 \\
1\end{array}$ & $\begin{array}{c}0.0 \\
4\end{array}$ & $\begin{array}{c}0.0 \\
7\end{array}$ & $\begin{array}{c}0.2 \\
5\end{array}$ & $\begin{array}{c}0.0 \\
6\end{array}$ & $\begin{array}{c}0.0 \\
6\end{array}$ & $\begin{array}{c}0.1 \\
1\end{array}$ & $\begin{array}{c}0.0 \\
2\end{array}$ & $\begin{array}{c}0.0 \\
4\end{array}$ & $\begin{array}{c}0.1 \\
5\end{array}$ & $\begin{array}{c}0.1 \\
5\end{array}$ \\
\hline Setiaji & $\begin{array}{c}0.0 \\
5\end{array}$ & $\begin{array}{c}0.1 \\
6\end{array}$ & $\begin{array}{c}0.1 \\
4\end{array}$ & $\begin{array}{c}0.0 \\
6\end{array}$ & $\begin{array}{c}0.0 \\
7\end{array}$ & $\begin{array}{c}0.0 \\
4\end{array}$ & $\begin{array}{c}0.0 \\
6\end{array}$ & $\begin{array}{c}0.1 \\
4\end{array}$ & $\begin{array}{c}0.0 \\
6\end{array}$ & $\begin{array}{c}0.0 \\
6\end{array}$ & $\begin{array}{c}0.1 \\
1\end{array}$ & $\begin{array}{c}0.0 \\
2\end{array}$ & $\begin{array}{c}0.0 \\
5\end{array}$ & $\begin{array}{c}0.1 \\
3\end{array}$ & $\begin{array}{c}0.1 \\
5\end{array}$ \\
\hline $\begin{array}{l}\text { Nurjana } \\
\mathrm{h}\end{array}$ & $\begin{array}{c}0.0 \\
5\end{array}$ & $\begin{array}{c}0.1 \\
9\end{array}$ & $\begin{array}{c}0.1 \\
1\end{array}$ & $\begin{array}{c}0.0 \\
8\end{array}$ & $\begin{array}{c}0.1 \\
8\end{array}$ & $\begin{array}{c}0.0 \\
1\end{array}$ & $\begin{array}{c}0.0 \\
9\end{array}$ & $\begin{array}{c}0.2 \\
2\end{array}$ & $\begin{array}{c}0.0 \\
5\end{array}$ & $\begin{array}{c}0.0 \\
6\end{array}$ & $\begin{array}{c}0.1 \\
1\end{array}$ & $\begin{array}{c}0.0 \\
2\end{array}$ & $\begin{array}{c}0.0 \\
3\end{array}$ & $\begin{array}{c}0.1 \\
5\end{array}$ & $\begin{array}{c}0.0 \\
2\end{array}$ \\
\hline Wisnu & $\begin{array}{c}0.0 \\
1\end{array}$ & $\begin{array}{c}0.1 \\
6\end{array}$ & $\begin{array}{c}0.1 \\
2\end{array}$ & $\begin{array}{c}0.0 \\
2\end{array}$ & $\begin{array}{c}0.2 \\
5\end{array}$ & $\begin{array}{c}0.0 \\
2\end{array}$ & $\begin{array}{c}0.0 \\
6\end{array}$ & $\begin{array}{c}0.2 \\
2\end{array}$ & $\begin{array}{c}0.0 \\
5\end{array}$ & $\begin{array}{c}0.0 \\
1\end{array}$ & $\begin{array}{c}0.1 \\
2\end{array}$ & $\begin{array}{c}0.0 \\
2\end{array}$ & $\begin{array}{c}0.0 \\
4\end{array}$ & $\begin{array}{c}0.1 \\
7\end{array}$ & $\begin{array}{c}0.0 \\
2\end{array}$ \\
\hline Purba & $\begin{array}{c}0.0 \\
1\end{array}$ & $\begin{array}{c}0.1 \\
9\end{array}$ & $\begin{array}{c}0.1 \\
1\end{array}$ & $\begin{array}{c}0.0 \\
8\end{array}$ & $\begin{array}{c}0.2 \\
8\end{array}$ & $\begin{array}{c}0.0 \\
2\end{array}$ & $\begin{array}{c}0.0 \\
8\end{array}$ & $\begin{array}{c}0.1 \\
9\end{array}$ & $\begin{array}{c}0.0 \\
5\end{array}$ & $\begin{array}{c}0.0 \\
1\end{array}$ & $\begin{array}{c}0.1 \\
4\end{array}$ & $\begin{array}{c}0.1 \\
6\end{array}$ & $\begin{array}{c}0.0 \\
4\end{array}$ & $\begin{array}{c}0.1 \\
5\end{array}$ & $\begin{array}{c}0.0 \\
2\end{array}$ \\
\hline Endang & $\begin{array}{c}0.0 \\
1\end{array}$ & $\begin{array}{c}0.1 \\
6\end{array}$ & $\begin{array}{c}0.1 \\
2\end{array}$ & $\begin{array}{c}0.0 \\
3\end{array}$ & $\begin{array}{c}0.0 \\
7\end{array}$ & $\begin{array}{c}0.0 \\
4\end{array}$ & $\begin{array}{c}0.0 \\
5\end{array}$ & $\begin{array}{c}0.1 \\
4\end{array}$ & $\begin{array}{c}0.0 \\
4\end{array}$ & $\begin{array}{c}0.0 \\
6\end{array}$ & $\begin{array}{c}0.1 \\
1\end{array}$ & $\begin{array}{c}0.1 \\
6\end{array}$ & $\begin{array}{c}0.0 \\
5\end{array}$ & $\begin{array}{c}0.1 \\
7\end{array}$ & $\begin{array}{c}0.1 \\
5\end{array}$ \\
\hline Maulid & $\begin{array}{c}0.0 \\
5\end{array}$ & $\begin{array}{c}0.2 \\
1\end{array}$ & $\begin{array}{c}0.1 \\
4\end{array}$ & $\begin{array}{c}0.0 \\
7\end{array}$ & $\begin{array}{c}0.2 \\
5\end{array}$ & $\begin{array}{c}0.0 \\
1\end{array}$ & $\begin{array}{c}0.0 \\
6\end{array}$ & $\begin{array}{c}0.1 \\
7\end{array}$ & $\begin{array}{c}0.0 \\
4\end{array}$ & $\begin{array}{c}0.0 \\
1\end{array}$ & $\begin{array}{c}0.1 \\
1\end{array}$ & $\begin{array}{c}0.1 \\
6\end{array}$ & $\begin{array}{c}0.0 \\
4\end{array}$ & $\begin{array}{c}0.2 \\
0\end{array}$ & $\begin{array}{c}0.1 \\
5\end{array}$ \\
\hline Herman & $\begin{array}{c}0.0 \\
5\end{array}$ & $\begin{array}{c}0.1 \\
4\end{array}$ & $\begin{array}{c}0.0 \\
8\end{array}$ & $\begin{array}{c}0.0 \\
8\end{array}$ & $\begin{array}{c}0.3 \\
2\end{array}$ & $\begin{array}{c}0.0 \\
4 \\
\end{array}$ & $\begin{array}{c}0.0 \\
8\end{array}$ & $\begin{array}{c}0.1 \\
9\end{array}$ & $\begin{array}{c}0.0 \\
5\end{array}$ & $\begin{array}{c}0.0 \\
6\end{array}$ & $\begin{array}{c}0.0 \\
8\end{array}$ & $\begin{array}{c}0.1 \\
6\end{array}$ & $\begin{array}{c}0.0 \\
3\end{array}$ & $\begin{array}{c}0.1 \\
5\end{array}$ & $\begin{array}{c}0.0 \\
2\end{array}$ \\
\hline SIP A+ & $\begin{array}{c}0.0 \\
5\end{array}$ & $\begin{array}{c}0.2 \\
1\end{array}$ & $\begin{array}{c}0.1 \\
4\end{array}$ & $\begin{array}{c}0.0 \\
1\end{array}$ & $\begin{array}{c}0.0 \\
7\end{array}$ & $\begin{array}{c}0.0 \\
4\end{array}$ & $\begin{array}{c}0.0 \\
9\end{array}$ & $\begin{array}{c}0.1 \\
4\end{array}$ & $\begin{array}{c}0.0 \\
7\end{array}$ & $\begin{array}{c}0.0 \\
1\end{array}$ & $\begin{array}{c}0.0 \\
8\end{array}$ & $\begin{array}{c}0.0 \\
2\end{array}$ & $\begin{array}{c}0.0 \\
5\end{array}$ & $\begin{array}{c}0.2 \\
0\end{array}$ & $\begin{array}{c}0.0 \\
2\end{array}$ \\
\hline SIP A & $\begin{array}{c}0.0 \\
1\end{array}$ & $\begin{array}{c}0.1 \\
2\end{array}$ & $\begin{array}{c}0.0 \\
8\end{array}$ & $\begin{array}{c}0.0 \\
8\end{array}$ & $\begin{array}{c}0.3 \\
2\end{array}$ & $\begin{array}{c}0.0 \\
1\end{array}$ & $\begin{array}{c}0.0 \\
5\end{array}$ & $\begin{array}{c}0.2 \\
5\end{array}$ & $\begin{array}{c}0.0 \\
4\end{array}$ & $\begin{array}{c}0.0 \\
6\end{array}$ & $\begin{array}{c}0.1 \\
4\end{array}$ & $\begin{array}{c}0.1 \\
6\end{array}$ & $\begin{array}{c}0.0 \\
3\end{array}$ & $\begin{array}{c}0.1 \\
3\end{array}$ & $\begin{array}{c}0.1 \\
5\end{array}$ \\
\hline
\end{tabular}


Tabel 9. Nilai Preferensi Alternatif

\begin{tabular}{|l|l|l|l|}
\hline Alternatif & D + & D- & Pref \\
\hline Susanto & 0.24 & 0.21 & 0.47 \\
\hline Dewi & 0.31 & 0.19 & 0.39 \\
\hline Agung & 0.22 & 0.27 & 0.55 \\
\hline Setiaji & 0.18 & 0.32 & 0.65 \\
\hline Nurjanah & 0.18 & 0.26 & 0.59 \\
\hline Wisnu & 0.22 & 0.24 & 0.52 \\
\hline Purba & 0.56 & 0.18 & 0.24 \\
\hline Endang & 0.54 & 0.29 & 0.35 \\
\hline Maulid & 0.28 & 0.19 & 0.40 \\
\hline Herman & 0.32 & 0.17 & 0.34 \\
\hline
\end{tabular}

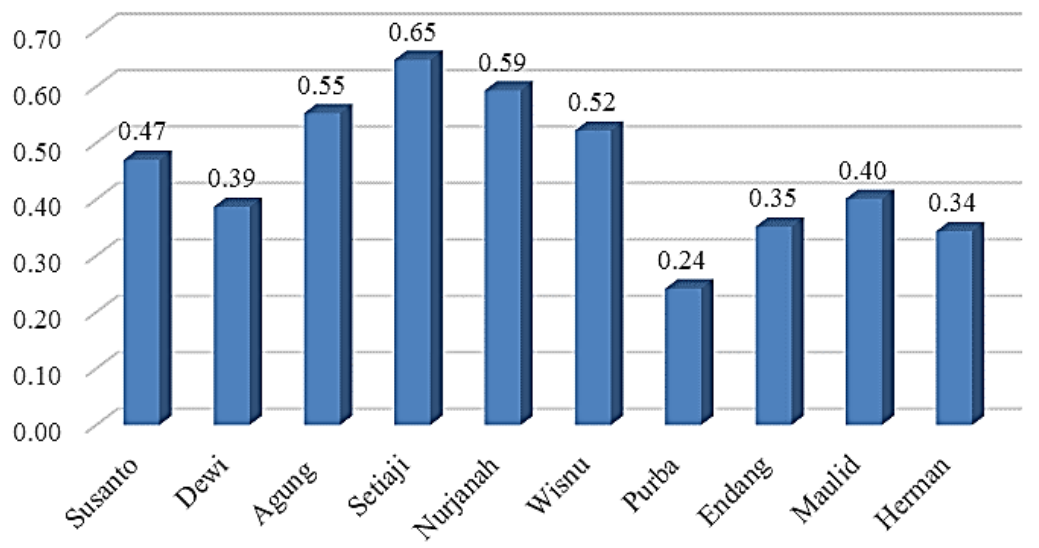

Gambar 3. Nilai Preferensi Alternatif TOPSIS

\subsection{TOPSIS}

Setelah dikembangkan perbandingan kriteria dengan AHP, tahap selanjutnya adalah mengevaluasi alternatif dengan menggunakan TOPSIS. Terdapat 10 pemohon yang dilakukan evaluasi (atas permintaan BPR, nama pemohon merupakan nama samaran). Setiap pemohon diberikan skor sesuai dengan situasi dan kondisi pada saat dilakukan survei. Skala yang digunakan untuk menilai pemohon adalah nilai 1 untuk menandakan negativitas dan nilai 9 untuk positif terbaik. Khusus untuk C11 (Cek BI), C41 (BPKB Berfaktur) dan C53 (Mencapai Target Pengucuran Kredit) hanya nilai positif dan negatif terbesar yang digunakan karena tipe penilaiannya bersifat ya dan tidak,ya dinyatakan dengan sangat positif (9) dan tidak dinyatakan dengan sangat negatif (1). Hasil penilaian pemohon kredit dapat dilihat pada tabel 6 .

Nilai-nilai pada skor setiap sub kriteria akan digunakan untuk membangun matriks keputusan ternormalisasi (normalized decision matrix). Elemen $\mathrm{r}_{\mathrm{ij}}$ hasil dari normalisasi didapatkan dari kuadrat tiap nilai dan dijumlahkan perkolom kemudian total penjumlahan tersebut diakarkan, kemudian hasil akar tersebut digunakan untuk membagi nilai-nilai pada kolom tersebut sehingga hasilnya dapat dilihat pada tabel 7 .

Matriks keputusan ternormalisasi terbobot (weighted normalized decision matrix)diperoleh dengan mengalikan setiap baris pada matriks keputusan ternormalisasi (tabel 7) dengan bobot masingmasing kriteria yang telah diperoleh melalui perhitungan AHP sebelumnya (tabel 5).

Matriks keputusan ternormalisasi terbobot akan menentukan solusi ideal positif $\left(\mathrm{A}^{+}\right)$dan solusi ideal negatif $\left(\mathrm{A}^{-}\right)$. Solusi ideal positif $\left(\mathrm{A}^{+}\right)$diperoleh dari nilai terbesar dari tiap kolom kriteria yang merupakan atribut benefit yaitu kriteria C11, C12, C13, C21, C22, C23, C31, C32, C33, C41, C42, C43, C51, C52.

Sedangkan ideal positif $\left(\mathrm{A}^{+}\right)$untuk kriteria C21, C22, C23, C31, C32, C33, C41, C42, C43, C51, C52, C53diperoleh dari nilai terkecil dari tiap kolom kriteria yang merupakan atribut biaya. Solusi ideal negatif $\left(\mathrm{A}^{-}\right)$di peroleh dari nilai terkecil dari tiap kolom kriteria yang merupakan atribut benefit, sedangkan solusi ideal negatif $\left(\mathrm{A}^{-}\right)$untuk atribut biaya diperoleh dari nilai maksimum dari tiap kolom kriteria biaya.

Untuk menghitung separation measure ideal positif $\left(\mathrm{S}^{+}\right)$yaitu dengan mengurangi nilai matriks keputusan ternormalisasi terbobot dengan nilai solusi ideal positif $\left(\mathrm{A}^{+}\right)$lalu di kuadratkankemudian dijumlahkan tiap barisnya, hasil dari penjumlahan itu kemudian diakarkuadratkan untuk menghasilkan separation measure ideal positif $\left(\mathrm{S}^{+}\right)$.Sedangkan untuk menghasilkan separation measure ideal negatif $\left(\mathrm{S}^{-}\right)$dilakukan dengan cara yang sama dengan nilai solusi ideal negatif $\left(\mathrm{A}^{-}\right)$. 
Hasil perhitungan separation measure ideal positif dan separation measure ideal negatif digunakan untuk menentukan nilai preferensi setiap alternatif $\left(\mathrm{C}_{\mathrm{i}}\right)$. Nilai preferensi di peroleh dengan cara membagi nilai separation measure ideal negatif $\left(\mathrm{S}^{-}\right)$dengan jumlah dari separation measure ideal positif $\left(\mathrm{S}^{+}\right)$dan separation measure ideal negatif $\left(\mathrm{S}^{-}\right)$. Nilai preferensi setiap alternatif digunakan untuk menentukan diterima atau ditolaknya pengajuan kredit mobil tiap-tiap alternatif seperti terlihat pada Tabel 9.

\subsection{PEMBAHASAN}

Bila dilihat dari hasil AHP dan TOPSIS, Purba menempati pilihan terakhir dengan skor preferensi 0.24 dibandingkan dengan Setiaji yang mendapatkan nilai preferensi 0.65. Dilihat dari Character, Purba hanya mendapatkan nilai negatif dari tidak lulus Cek BI, tetapi Sikap dan Kejujuran serta Kondisi di Rumah mendapatkan nilai yang tinggi. Dari kriteria Capacity, Purba juga termasuk mempunyai penghasilan sendiri yang cukup tinggi disertai dengan penghasilan keluarga yang juga tinggi, selain itu Purba mempunyai performa kredit sebelumnya yang tidak bermasalah. Dari Capital, Purba juga mempunyai aset lunas yang tinggi, dengan jumlah hutang yang rendah dan tabungan yang mencukupi. Pada Collateral, mobil yang diajukan Purba tidak mempunyai faktur, tetapi DP minimal untuk pengajuan kredit tercapai dan mobil juga dalam kondisi yang sangat layak untuk dijual kembali. Pada kriteria Condition, Purba mengajukan kredit dalam jangka waktu pendek dengan suku bunga diatas rata-rata yang berarti menguntungkan perusahaan. Selain itu, pengucuran kredit untuk Purba bukan dalam rangka mencapai target pengucuran kredit.

Berbeda dengan Setiaji yang mendapatkan nilai preferensi tertinggi pada pemilihan pemohon kredit. Setiaji lulus Cek BI, Sikap dan Kejujuran tinggi, serta kondisi dan situasi di rumah yang baik. Penghasilan Keluarga cukup tinggi, tetapi Penghasilan Sendiri berada dalam kategori tidak mampu. Performa kredit sebelumnya dari Setiaji sangat bagus. Dari segi Capital, Aset Setiaji yang sudah lunas dan hutang yang ada dalam kisaran menengah, tetapi tabungan cukup bagus. BPKB Berfaktur, tetapi kondisi mobil kalah nilainya dibanding mobil yang diajukan Purba, selain itu, DP minimal Setiaji juga tidak tercapai. Jangka waktu Kredit pendek, suku bunga cukup menguntungkan, dan pengucuran kredit dilakukan dalam rangka mengejar target kredit.

Dari kedua sisi preferensi yang paling rendah sampai paling tinggi pemohon kredit dapat dilihat bahwa hanya mempertimbangkan satu sisi saja dari kriteria penilaian tidaklah cukup. Beberapa sub kriteria dari kriteria utama sangat membantu dalam pembuatan keputusan yang lebih objektif sesuai preferensi pembuat keputusan. Terdapat banyak pertimbangan yang kontradiktif yang apabila keputusannya diambil secara subjektif akan tidak menghasilkan keputusan yang baik karena membingungkan.

Misalnya Setiaji tidak mencukupi DP minimal, penghasilan sendiri juga tidak mampu, kondisi mobil kalah dibanding Purba, tetapi Characternya sangat baik, mempunyai tabungan cukup dengan performa kredit sebelumnya yang cukup, jangka waktu pengajuan kreditnya juga pendek dengan suku bunga tinggi dan dengan mengucurkan kredit akan mencapai target pengucuran kredit pihak bank. Purba hanya tidak lulus Cek BI, mobil tidak mempunyai faktur, dan pengucuran kredit bukan untuk mencapai target pengucuran kredit bank, selain itu Purba mendapatkan nilai baik di alternatif kriteria lainnya. Tetapi setelah digunakan pendukung keputusan, Purba tidak menjadi pilihan utama karena preferensi yang sudah ditentukan pembuat keputusan sebelumnya.

Dengan adanya pendukung keputusan, pihak bank akan lebih baik dalam mengambil keputusan karena apabila pihak bank hanya menggunakan syarat administratif sebagai kriteria pengucuran kredit, maka ada banyak potensi keuntungan yang hilang. Sedangkan dengan menggunakan banyak pertimbangan akan membuat kebingungan karena banyak yang harus dipikirkan secara bersamaan.

Di sisi lain apabila skor preferensi diberikan standar misalnya preferensi dibawah 0.5 maka termasuk tidak favorit dan diatas 0.5 adalah favorit, maka dapat ditemukan informasi tambahan seperti pemohon dengan skor favorit ada yang tidak lulus cek BI sedangkan yang di bagian yang tidak favorit ada pemohon yang lulus. Penghasilan Keluarga terendah didapatkan di pemohon skor favorit sedangkan skor tidak favorit malah terdapat penghasilan keluarga tertinggi. 
Di pemohon favorit juga terlihat ada yang penghasilan sendirinya masih tidak mencukupi atau berada dibawah penghasilan pemohon yang tidak favorit. Selain itu, di pemohon favorit juga terlihat ada yang mendapatkan skor performa kredit sebelumnya yang rendah. Pada aset lunas, hutang dan tabungan tidak terdapat perbedaan mencolok diantara kedua pemohon yang kategori favorit dan tidak favorit. di bagian favorit juga terlihat ada yang tidak memiliki faktur di BPKB sedangkan kondisi mobil pada umumnya berada diatas rata-rata.

Informasi lainnya yang kontradiktif adalah hampir semua pemohon yang dikategorikan favorit tidak memenuhi syarat DP minimal. Kebalikan dengan yang tidak favorit dimana ketiga terbawah mencapai DP minimal. Untuk jangka waktu dan suku bunga tidak terdapat perbedaan mencolok. Pada mencapai target pengucuran kredit juga berimbang antara yang mendapatkan skor favorit dan tidak favorit.

\section{KESIMPULAN}

AHP dan TOPSIS berhasil digunakan sebagai pendukung pembuat keputusan yang memerlukan banyak pertimbangan sekaligus. Pada tipe keputusan seperti itu AHP dan TOPSIS akan memberikan keputusan yang lebih objektif dan preferensi dapat dibedakan dengan jelas. Khusus untuk pemberian kredit mobil pada BPR, pendukung keputusan akan membantu pihak bank untuk mengevaluasi kembali kelompok pemohon kredit yang secara administratif tidak lulus tetapi berpotensi memberikan keuntungan bagi pihak bank.

\section{SARAN}

Pada penelitian selanjutnya dapat dikembangkan pengambilan keputusan berkelompok. Pembobotan dapat digunakan untuk penilaian kelompok sehingga pembuat keputusan utama mendapatkan bobot yang lebih besar. Pada penelitian selanjutnya juga dapat dikembangkan sistem pendukung keputusan yang dapat merubah preferensi maupun kriteria secara fleksibel dengan perangkat lunak.

\section{DAFTAR PUSTAKA}

[1] Otoritas Jasa Keuangan , 2017, Bank Umum, http://www.ojk.go.id/id/kanal/perbankan/Pag es/Bank-Umum. aspx, diakses 10-01-2017

[2] Bank Indonesia, 2017, Ikhtisar Perbankan, http://www.bi.go.id/id/perbankan/ikhtisar/lemba ga/Contents/Default.aspx, diakses 11-01-2017

[3] Otoritas Jasa Keuangan, 2017, Bank Perkreditan Rakyat, http://www.ojk.go.id/id/kanal /perbankan/Pages/Bank-Perkredi tan-Rakyat.aspx, diakses 10-02-2017

[4] Dedy, Mirna, 2016, Aset BPR Kalbar Mengalami Perlambatan, http://pontianak.tribunnews. com/2016/02/17/aset-bpr-kalbar-mengalami-perlambatan, diakses 15-01-2017

[5] Greatness, Steven, 2014, Bank Centradana Kapuas Tiga Kali Berturut-turut mendapatkan Infobank Award, http://pontianak.tribunnews.com/2014/09/02/bank-centradana-kapuas-tiga -kaliberturut-raih-infobank-award, diakses tanggal 11-01-2017

[6] ERTUĞ, Z. K., 2014, The Data Envelopment Analytic Hierarchy Process (DEAHP) Approach in the Evaluation of Commercial Credit Applications, European Journal of Business and Management, vol 6 no 35, hal 132-146,

[7] Yurdakul, M., Tansel, Y., 2004, AHP approach in the credit evaluation of the manufacturing firms in Turkey, International Journal of Production Economics, vol 88, hal269-289

[8] Mandic, K., Delibasic, B., Knezevic, S., Benkovic, S., 2014, Analysis of the financial parameters of serbian banks through the application of the fuzzy AHP and TOPSIS methods, Enonomic Modelling, vol 43, hal 30-37

[9] Karim, R., Karmaker, C. L., 2016, Machine Selection by AHP and TOPSIS Methods. American Journal of Industrial Engineering, Vol 4 No 1 Hal 7-13.

[10] Saaty, T. L. 2008, Decision making with the analytic hierarchy process. International journal of services sciences Vol 1 No1, hal 83-98. 
[11]Saaty, Thomas L., 2000, Fundamentals of Decision Making and Priority Theory with The Analytic Hierarchy Process (Analytic Hierarchy Process Series, Vol. 6), First Edition, RWS Publications.

[12]Yoon, K., Hwang, Ching-Lai., Multiple Attribute Decision Making: Methods and Applications. A State-of-the-art Survey, Berlin, Heidelberg, New York: Springer-Verlag, 1981.

[13] Kusumadewi, S., Hartati, S., Harjoko, A., \& Wardoyo, R. Fuzzy Multi-Atribute Decision Making (1st Edition ed.). Yogyakarta: Graha Ilmu, 2006 